\title{
Escherichia coli 5' -Nucleotidase: Purification, Properties and its Release by Osmotic Shock
}

\author{
By D. F. BROAD* AND J. T. SMITH \\ The Microbiology Section, Department of Pharmaceutics, The School of Pharmacy, \\ 29/39 Brunswick Square, London WC1N 1AX
}

(Received 11 June 1980; revised 25 September 1980)

\begin{abstract}
Escherichia coli 5'-nucleotidase was purified to apparent homogeneity as judged by polyacrylamide gel electrophoresis. Its molecular weight was estimated by sodium dodecyl sulphate-polyacrylamide gel electrophoresis, by gel exclusion chromatography, and by membrane filtration; values of 66000,48500 , and 15000 to 30000 , respectively, were obtained. The enzyme was completely released from bacteria by osmotic shock treatment. The apparently anomalous behaviour of $5^{\prime}$-nucleotidase in terms of the molecular sieving hypothesis for the release of enzymes by osmotic shock proposed by Smith \& Wyatt (1974) and extended by Broad \& Smith (1979) is discussed.
\end{abstract}

\section{INTRODUCTION}

$5^{\prime}$-Nucleotidase (5'-ribonucleotide phosphohydrolase; EC 3.1.3.5) is a member of a group of degradative enzymes which are released by osmotic shock from Escherichia coli (Neu \& Heppel, 1964) and other members of the Enterobacteriaceae (Neu \& Chou, 1967). This process partially disrupts the cell wall of Gram-negative bacteria, such as $E$. coli, without causing loss of viability. As a result of osmotic shock damage, certain enzymes are released from the organism, although the majority of bacterial enzymes are not.

Enzymes released by osmotic shock have been assigned to a discrete cellular location, the periplasm (Heppel, 1971), which is assumed to be located between the cytoplasmic membrane and the outer membrane (Mitchell, 1961); enzymes that are not released have been assumed to exist within the cytoplasm, and are termed cell-bound (Heppel, 1971). However, contrary to this view, Smith \& Wyatt (1974) found that the release of $\beta$-lactamases by osmotic shock was governed solely by the molecular weight of the enzyme, so that the cell wall seemed to be acting as a molecular sieve, restricting the release of $\beta$-lactamases with molecular weights of 30000 or more. The release of $5^{\prime}$-nucleotidase, which has a molecular weight of 52000 (Neu, 1967a), appears to contradict this molecular sieving hypothesis. However, Broad \& Smith (1979) have extended the hypothesis to include the release of $\beta$-lactamases with molecular weights greater than 30000 . The $\beta$-lactamases specified by plasmids R46 and R55, which have molecular weights of 44600 and 41200 , respectively (Dale, 1971; Dale \& Smith, 1974) are released to some extent by osmotic shock treatment. This might occur because these enzymes consist of two identical sub-units (Dale \& Smith, 1976). The sub-units could be sufficiently small or the native enzymes themselves could be sufficiently elongated to pass through the cell wall during osmotic shock treatment. Thus, the cell wall acts as a molecular sieve retaining globular proteins of molecular weight 30000 or more. Release of $E$. coli $5^{\prime}$-nucleotidase could similarly be reconciled with the molecular sieving hypothesis should it too be found to consist of sub-units or to be an asymmetric, monomeric enzyme. To this end, we have purified 5'-nucleotidase to apparent homogeneity and studied its physical properties. 


\section{METHODS}

Materials. Chemicals were obtained from commercial sources; reagents for electrophoresis were from B.D.H.; amido black was from G. C. Gurr; marker proteins, except for bovine serum albumin (obtained from Armour Pharmaceuticals), were from Koch-Light; and nucleotides were obtained from Sigma.

Organisms. Strains were taken from stock cultures stored in liquid nitrogen in this laboratory. For routine use, the cultures were kept on nutrient agar slopes at $4^{\circ} \mathrm{C}$. Escherichia coli $\mathrm{K} 12$ strain $\mathrm{J} 6.2$ was described by Clowes \& Rowley (1954); it is $\mathrm{F}^{-}$, requires proline, histidine and tryptophan, and does not ferment lactose.

Resistance plasmids. Plasmid R55 was first described by Witchitz \& Chabbert (1971) and plasmid R46 (R. Brighton, R 1818) by Anderson \& Datta (1965).

$5^{\prime}$-Nucleotidase assay. Before assaying the activity of $5^{\prime}$-nucleotidase in crude enzyme extracts, the cytoplasmic inhibitor of the enzyme was inactivated by diluting the enzyme sample in distilled water and incubating at $37^{\circ} \mathrm{C}$ for $1 \mathrm{~h}(\mathrm{Neu}, 1967 \mathrm{~b})$. This treatment was only necessary for crude extracts because the inhibitor was not released by osmotic shock. The assay consisted of two parts: hydrolysis of the substrate by 5 '-nucleotidase followed by measurement of the resultant release of phosphate. For the routine assay of 5'-nucleotidase, 5'-AMP was used as substrate and phosphate was estimated by the method of Chen et al. (1956). The procedure used was that of Neu $(1967 a)$ as adapted by Wyatt (1972). One unit of $5^{\prime}$-nucleotidase activity is the amount of enzyme which catalyses the release of $1 \mu \mathrm{mol}$ phosphate $\min ^{-1}$ at $37^{\circ} \mathrm{C}$.

Protein assay. Protein was assayed spectrophotometrically in $25 \mathrm{~mm}-\mathrm{Na}_{2} \mathrm{HPO}_{4} / \mathrm{NaH}_{2} \mathrm{PO}_{4}$ buffer (pH 7.4) by the method of Waddell (1956).

Purification of E. coli 5'-nucleotidase.

(i) Growth of bacteria. Escherichia coli $\mathrm{J} 6.2$ was grown with aeration for $16 \mathrm{~h}$ at $37^{\circ} \mathrm{C}$ in 501 of minimal salts medium (Davis \& Mingioli, 1950) supplemented with $0.28 \%(\mathrm{w} / \mathrm{v})$ glucose and the appropriate L-amino acids $\left(40 \mu \mathrm{g} \mathrm{ml}^{-1}\right.$ each). The bacteria were harvested in the stationary phase of growth using a Griffin-Christ 1500 continuous flow centrifuge at $9000 \mathrm{~g}$ with a flow rate of $200 \mathrm{ml} \mathrm{min}^{-1}$. The bacterial pellet was washed with minimal salts medium lacking glucose and resuspended in 21 of ice-cold $0.01 \mathrm{M}$-Tris/ $\mathrm{HCl}$ buffer (pH 7.3) containing $0.03 \mathrm{M}-\mathrm{NaCl}$.

(ii) Osmotic shock. The procedure used was that of Smith \& Wyatt (1974) which is based on a procedure for cells in the stationary phase of growth described by Neu \& Chou (1967). The resuspended bacteria were centrifuged at $5000 \mathrm{~g}$ for $20 \mathrm{~min}$ at $4{ }^{\circ} \mathrm{C}$ and the pellet was resuspended in 21 of $0.03 \mathrm{M}$-Tris/ $\mathrm{HCl}$ buffer (pH 7.3) containing $20 \%(\mathrm{w} / \mathrm{v})$ sucrose at room temperature. EDTA solution $\left(10 \mathrm{mg} \mathrm{m}^{-1}\right)$ was added to give $1 \mathrm{mM}$. The cells were stirred for $5 \mathrm{~min}$ at room temperature followed by centrifugation at $5000 \mathrm{~g}$ for $20 \mathrm{~min}$ at $4^{\circ} \mathrm{C}$. The pellet was rapidly resuspended in 21 of ice-cold water and stirred for $5 \mathrm{~min}$ before centrifuging again. The resultant 'osmotic-shock supernatant' was used as the source of 5 '-nucleotidase for purification. This supernatant was concentrated by freeze-drying, and then the lyophilized sample was suspended in $20 \mathrm{ml}$ of cold $5 \mathrm{~mm}-\mathrm{Tris} / \mathrm{HCl}$ buffer ( $\mathrm{pH} \mathrm{7.3)} \mathrm{containing} 1 \mathrm{mM}-\mathrm{MgCl}_{2}$ and $0.5 \mathrm{mM}-\mathrm{CoCl}_{2}$ (buffer $\mathrm{A}$ ) and dialysed for $18 \mathrm{~h}$ at $4{ }^{\circ} \mathrm{C}$ against 21 of buffer $\mathrm{A}$.

(iii) DEAE-cellulose chromatography. The dialysed sample was loaded on to a Wright, acrylic jacketed column $\left(2 \mathrm{~cm}^{2} \times 30 \mathrm{~cm}\right)$ packed with DEAE-cellulose ion-exchange resin (Whatman, DE52) equilibrated with buffer A. The column was maintained at $4{ }^{\circ} \mathrm{C}$ using a Camlab Fracpac cooled fraction collector fitted with a circulation pump. The sample was washed on to the column with buffer A which was passed through the column at a rate of $48 \mathrm{ml} \mathrm{h}^{-1}$. The effluent from the column was monitored for protein by its absorbance at $280 \mathrm{~nm}$. When this fell to zero it was assumed that all the unbound protein had been eluted from the column. A linear gradient from 0 to $0.2 \mathrm{M}-\mathrm{NaCl}$ in $200 \mathrm{ml}$ of buffer $\mathrm{A}$ was then applied and $5 \mathrm{ml}$ fractions were collected and stored at $4{ }^{\circ} \mathrm{C}$. The 5 '-nucleotidase activity of each fraction was then estimated.

(iv) Gel exclusion chromatography. Fractions collected from DEAE-cellulose chromatography containing the highest $5^{\prime}$-nucleotidase activity were pooled, dialysed for $18 \mathrm{~h}$ against 100 vol. distilled water at $4{ }^{\circ} \mathrm{C}$, and then freeze-dried. The lyophilized sample was resuspended in $2 \mathrm{ml}$ of cold buffer $\mathrm{A}$ and applied to the bottom of a Wright, acrylic jacketed column $\left(4 \mathrm{~cm}^{2} \times 60 \mathrm{~cm}\right)$ packed with Sephadex G-100 (Pharmacia) equilibrated with buffer $\mathrm{A}$. The column was kept at $4{ }^{\circ} \mathrm{C}$ by a Camlab Fracpac fraction collector fitted with a circulation pump. The sample was pumped upwards at a rate of $30 \mathrm{ml} \mathrm{h}^{-1}$ and $3 \mathrm{ml}$ fractions were collected and stored at $4{ }^{\circ} \mathrm{C}$. These were assayed for protein content and $5^{\prime}$-nucleotidase activity. The fractions with peak activity were pooled and kept for further studies.

Molecular weight estimation by gel exclusion chromatography. Molecular weights were estimated by the method of Andrews (1964). Samples (0.1 ml of $10 \mathrm{mg} \mathrm{ml}^{-1}$ solutions) of standard proteins of known molecular weights (bovine serum albumin, ovalbumin, chymotrypsinogen $\mathrm{A}$ and cytochrome $c$ ) were applied to the same Sephadex G- 100 column as used in the purification of 5'-nucleotidase and $3 \mathrm{ml}$ fractions were collected; the protein peaks in the fractions were detected spectrophotometrically at $230 \mathrm{~nm}$ (cytochrome $c$ was detected at $412 \mathrm{~nm}$ ). The elution volume $\left(V_{\mathrm{e}}\right)$ of each protein was calculated and plotted against $\log _{10}$ (molecular weight). Using this calibration curve and the $V_{\mathrm{e}}$ of the $5^{\prime}$-nucleotidase activity peak, the molecular weight of $5^{\prime}$-nucleotidase was calculated. 
$\beta$-Lactamase assay. $\beta$-Lactamase activity was estimated by the hydroxylamine method (Dale \& Smith, 1971).

Preparation of $\beta$-lactamase samples. Crude $\beta$-lactamase samples were prepared in $25 \mathrm{mM}-\mathrm{Na}_{2} \mathrm{HPO}_{4} / \mathrm{NaH}_{2} \mathrm{PO}_{4}$ buffer (pH 7.4) as described by Hedges et al. (1974).

Polyacrylamide gel electrophoresis $(P A G E)$. Discontinuous PAGE was performed in a Shandon disc electrophoresis apparatus as described by Davis (1964) and modified by Dale (1970).

Sodium dodecyl sulphate (SDS)-PAGE. Molecular weight estimations by SDS-PAGE were carried out on $10 \%(\mathrm{w} / \mathrm{v})$ gels as described by Weber \& Osborn (1969).

Urea-PAGE. The system used was that of M. V. Kelemen (personal communication). The separating gel was made by mixing 1 vol. solution $\mathrm{A}$ ( $16 \mathrm{~g}$ acrylamide, $0.8 \mathrm{~g}$ bisacrylamide, $8 \mathrm{M}$-urea to $100 \mathrm{ml}$ ), 1 vol. solution $\mathrm{B}$

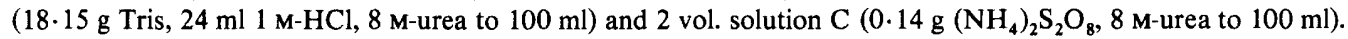
This gave a final acrylamide concentration of $4 \%(\mathrm{w} / \mathrm{v})$. The stacking gel was prepared by mixing 1 vol. solution $\mathrm{D}$ ( $8 \mathrm{~g}$ acrylamide, $0.8 \mathrm{~g}$ bisacrylamide, $8 \mathrm{M}$-urea to $100 \mathrm{ml}), 1$ vol. solution E $\left(2.23 \mathrm{~g}\right.$ Tris, $12.8 \mathrm{ml} 1 \mathrm{M}-\mathrm{H}_{3} \mathrm{PO}_{4}$, $8 \mathrm{M}$-urea to $100 \mathrm{ml}$ ) and 2 vol. solution $\mathrm{F}\left(4 \mathrm{mg}\right.$ riboflavin, $160 \mathrm{mg}\left(\mathrm{NH}_{4}\right)_{2} \mathrm{~S}_{2} \mathrm{O}_{8}, 8 \mathrm{M}$-urea to $\left.100 \mathrm{ml}\right)$. Gels were poured as for standard PAGE. The buffer used in the upper reservoir contained $2.58 \mathrm{~g}$ Tris, $1.74 \mathrm{~g}$ glycine, $350 \mathrm{ml}$ $8 \mathrm{M}$-urea and distilled water to $500 \mathrm{ml}$ (buffer B). Protein samples were dissolved in buffer B containing $0.01 \mathrm{M}$-EDTA and $1 \%(\mathrm{w} / \mathrm{v})$ 2-mercaptoethanol. The lower reservoir buffer contained $7.25 \mathrm{~g}$ Tris, $30 \mathrm{ml} 1 \mathrm{M}-\mathrm{HCl}$ and distilled water to $500 \mathrm{ml}$.

Electrophoresis was carried out using a constant current of $3.5 \mathrm{~mA}$ per electrophoresis tube until the tracking dye reached the bottom of the tubes (usually $1 \mathrm{~h}$ ). The mobility of the proteins was calculated by the method of Weber \& Osborn (1969). However, it was found that when proteins were run in separate gels, there was no simple correlation between mobility and $\log _{10}$ (molecular weight). This was presumably due to the urea affecting the polymerization of individual gels and was overcome by running the marker proteins and 5'-nucleotidase sample in the same gel, when a direct correlation between mobility and $\log _{10}$ (molecular weight) was observed. To facilitate recognition of the various protein bands only three marker proteins were used (bovine serum albumin, alcohol dehydrogenase and myoglobin).

Histochemical stain for the location of 5'-nucleotidase on polyacrylamide gels. The method used was that described by Dvorak \& Heppel (1968).

Treatment of proteins for SDS-PAGE and urea-PAGE. A $40 \mu \mathrm{g}$ sample of freeze-dried, pure 5'-nucleotidase and $40 \mu \mathrm{g}$ of each standard protein of known molecular weight were subjected to the following dissociative procedures: (a) incubation for $2 \mathrm{~h}$ at $37^{\circ} \mathrm{C}$ in $0.01 \mathrm{M}-\mathrm{Na}_{2} \mathrm{HPO}_{4} / \mathrm{NaH}_{2} \mathrm{PO}_{4}$ buffer $(\mathrm{pH} 7 \cdot 0)($ buffer $\mathrm{C})+1 \%(\mathrm{w} / \mathrm{v})$ $\mathrm{SDS}+1 \%(\mathrm{w} / \mathrm{v}) 2$-mercaptoethanol; $(b)$ as for $(a)$ followed by dialysis for $18 \mathrm{~h}$ at $20^{\circ} \mathrm{C}$ against buffer $\mathrm{C}+0 \cdot 1 \%$ $(\mathrm{w} / \mathrm{v}) \mathrm{SDS}+0.1 \%(\mathrm{w} / \mathrm{v}) 2$-mercaptoethanol; $(c)$ incubation at $100^{\circ} \mathrm{C}$ for $10 \mathrm{~min}$ in buffer $\mathrm{C}+1 \%(\mathrm{w} / \mathrm{v})$ SDS + 1\% (w/v) 2-mercaptoethanol + 0.01 M-EDTA; $(d)$ incubation for $1 \mathrm{~h}$ at room temperature in buffer $\mathrm{B}+1 \%(\mathrm{w} / \mathrm{v})$ 2-mercaptoethanol $+0.01 \mathrm{M}$-EDTA; $(e)$ as for $(d)$ followed by dialysis for $18 \mathrm{~h}$ at room temperature against buffer B $+1 \%(w / v)$ SDS $+1 \%(w / v) 2$-mercaptoethanol $+0 \cdot 01$ M-EDTA. Samples prepared by methods $(a),(b),(c)$ and $(e)$ were subjected to SDS-PAGE; samples prepared by method $(d)$ were subjected to urea-PAGE.

Membrane filtration. Membrane filters (Diaflo ultrafiltration membranes XM100A, XM50, PM30 and PM10; manufacturer's molecular weight 'cut-off' estimates 100000, 50000, 30000 and 15000, respectively) were obtained from Amicon, Lexington, Mass., U.S.A. Filtration was carried out using an Amicon high performance thin-channel filtration system, TCF10, according to the manufacturer's instructions, ensuring that pump speed and nitrogen pressure were the lowest possible to give an adequate filtration rate. Filters were calibrated using proteins of known molecular weight (those used for SDS-PAGE). Samples $\left(20 \mathrm{ml}\right.$ of $0.2 \mathrm{mg} \mathrm{ml}^{-1}$ solutions) of individual proteins in $25 \mathrm{~mm}-\mathrm{Na}_{2} \mathrm{HPO}_{4} / \mathrm{NaH}_{2} \mathrm{PO}_{4}$ buffer $(\mathrm{pH} \mathrm{7.4)}$ were filtered, and the protein concentrations in the filtrates were measured and compared with that in the unfiltered control to determine whether the protein had passed through the filter.

$\beta$-Lactamase samples used were crude preparations in $25 \mathrm{~mm}-\mathrm{Na}_{2} \mathrm{HPO}_{4} / \mathrm{NaH}_{2} \mathrm{PO}_{4}$ buffer (pH 7.4). The 5 -nucleotidase samples were osmotic shock supernatants of $E$. coli $\mathrm{J} 6.2$ in $0.05 \mathrm{M}-\mathrm{CH}_{3} \mathrm{COONa} / \mathrm{CH}_{3} \mathrm{COOH}$ buffer ( $\mathrm{pH} \mathrm{6.0)} \mathrm{(} \mathrm{pH}$ did not affect the filtration characteristics of $5^{\prime}$-nucleotidase in the range $\mathrm{pH} 6 \cdot 0$ to $7 \cdot 4$ ). Samples $(20 \mathrm{ml})$ of enzyme were filtered and the enzyme activity in the filtrates was measured. To allow for any inactivation of the enzymes the activity in each filtrate was expressed relative to that in the XM100A membrane filtrate.

\section{RESULTS AND DISCUSSION}

\section{Purification of 5'-nucleotidase}

Escherichia coli $5^{\prime}$-nucleotidase has previously been purified by Neu $(1967 a)$ and Dvorak \& Heppel (1968) using osmotic shock as a purification procedure followed by repeated steps 
Table 1. Purification of E. coli 5'-nucleotidase

\begin{tabular}{|c|c|c|c|c|c|c|c|}
\hline Sample & $\begin{array}{l}\text { Volume } \\
\text { (ml) }\end{array}$ & $\begin{array}{c}\text { Protein } \\
\text { concn } \\
\left(\mathrm{mg} \mathrm{ml}^{-1}\right)\end{array}$ & $\begin{array}{c}\text { Activity } \\
\left(\text { units } \mathrm{ml}^{-1} \text { ) }\right.\end{array}$ & $\begin{array}{c}\text { Specific } \\
\text { activity } \\
{[\text { [units }} \\
\left.\text { (mg protein })^{-1}\right]\end{array}$ & $\begin{array}{l}\text { Total } \\
\text { activity } \\
\text { (units) }\end{array}$ & $\begin{array}{c}\text { Recovery } \\
(\%)\end{array}$ & $\begin{array}{l}\text { Purification } \\
\text { factor }\end{array}$ \\
\hline Crude enzyme extract & 2000 & $7 \cdot 31$ & $0.52^{*}$ & 0.071 & 1040 & 100 & 1 \\
\hline $\begin{array}{l}\text { Osmotic-shock } \\
\text { supernatant }\end{array}$ & 2000 & 0.43 & 0.52 & $1 \cdot 21$ & 1040 & 100 & 17 \\
\hline $\begin{array}{l}\text { Osmotic-shock } \\
\text { supernatant, freeze- } \\
\text { dried, dialysed }\end{array}$ & 20 & $24 \cdot 9$ & $46 \cdot 6$ & 1.87 & 932 & 89.4 & 26 \\
\hline $\begin{array}{l}\text { Pooled DEAE-cellulose } \\
\text { fractions }(44-48)\end{array}$ & 25 & 0.187 & $31 \cdot 0$ & $166 \cdot 6$ & 775 & $74 \cdot 4$ & 2346 \\
\hline $\begin{array}{l}\text { DEAE-cellulose } \\
\text { fractions }(44-48), \\
\text { freeze-dried }\end{array}$ & $2 \cdot 5$ & 0.967 & $208 \cdot 5$ & $166 \cdot 0$ & 521 & $50 \cdot 1$ & 2338 \\
\hline $\begin{array}{l}\text { Pooled Sephadex } \\
\text { fractions }(36-40)\end{array}$ & 15 & 0.028 & $16 \cdot 0$ & 592.9 & 240 & $23 \cdot 0$ & 8350 \\
\hline
\end{tabular}

* The measured activity in the crude extract prepared by ultrasonic disruption was 0.23 units $\mathrm{ml}^{-1}$, but for the purposes of calculation the activity was assumed to be the same as that in the osmotic-shock supernatant (see text).

of ion-exchange chromatography. In this study, purification was achieved on the basis of size as well as charge in that gel exclusion chromatography was used after initial osmotic shock and ion-exchange chromatographic steps.

An overall purification of approximately 8000 -fold was obtained with respect to the activity in crude enzyme extract prepared by ultrasonic disruption (Table 1). The measured activity in the crude enzyme extract was 0.23 units $\mathrm{ml}^{-1}$, although for the purposes of calculation it was assumed to be 0.52 units $\mathrm{ml}^{-1}$, i.e. the same as the activity found in the osmotic-shock supernatant. The low activity of the extract prepared by ultrasonic disruption was found to be due to binding of $5^{\prime}$-nucleotidase to cell debris rather than to failure to completely inactivate the cytoplasmic inhibitor of 5'-nucleotidase. Two other enzymes released by osmotic shock (RNAase and non-specific acid phosphatase) are also known to bind to cell debris (Spahr \& Hollingworth, 1961). During the purification procedure, the osmotic-shock supernatant and the pooled DEAE-cellulose fractions ( 44 to 48 ) were concentrated by freeze-drying, which in both cases resulted in a considerable loss of total protein. This was due to the loss of small molecular weight peptides during the dialysis procedures used prior to ion-exchange chromatography of the freeze-dried osmotic-shock supernatant and prior to freeze-drying of the pooled DEAE-cellulose fractions (44 to 48).

$5^{\prime}$-Nucleotidase activity eluted as a single peak at an $\mathrm{NaCl}$ concentration of $0.125 \mathrm{M}$ during DEAE-cellulose chromatography, whereas the elution profile of $5^{\prime}$-nucleotidase activity from Sephadex G-100 demonstrated a shoulder of activity between fractions 34 and 35 (Fig. 1). This shoulder was observed in several different preparations and may represent an isoenzyme of higher molecular weight, since two bands of protein, very close together, were observed after SDS-PAGE of pure 5'-nucleotidase. Dvorak \& Heppel (1968) also observed two bands after standard PAGE of purified $5^{\prime}$-nucleotidase although we only observed one band.

\section{Purity of 5'-nucleotidase}

Samples taken at different stages during the purification procedure were examined for purity using PAGE. The gels were stained for protein using amido black and for 5'-nucleotidase activity using the Dvorak \& Heppel (1968) technique. 


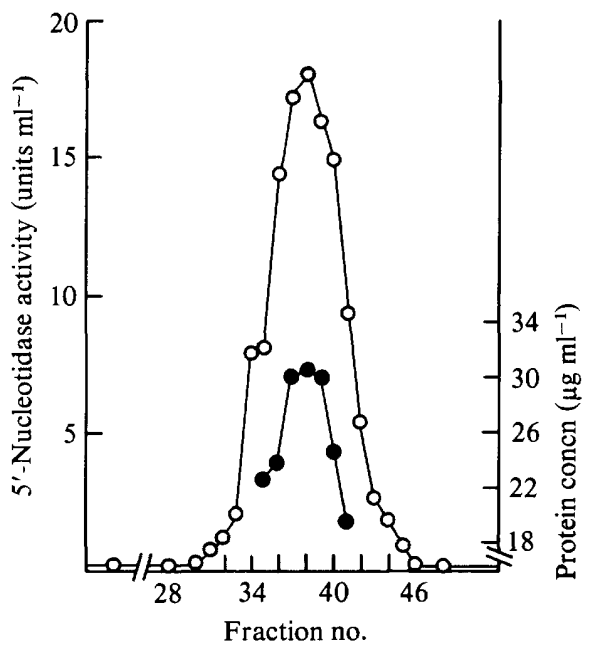

Fig. 1. Elution of $5^{\prime}$-nucleotidase activity during Sephadex G-100 gel exclusion chromatography: $O$, $5^{\prime}$-nucleotidase activity;, protein concentration.

After electrophoresis of the osmotic-shock supernatant about 12 protein bands were observed. Thus, the osmotic shock treatment represents a large purification step as would be expected since only $5.9 \%$ of the total cell protein is released by osmotic shock (Table 1 ). DEAE-cellulose chromatography removed several more proteins and the major band remaining corresponded to $5^{\prime}$-nucleotidase.

The pooled Sephadex fractions (36 to 40 ) contained only one protein band, which had a mobility corresponding to that of the $5^{\prime}$-nucleotidase band detected by the specific histochemical stain. From this we assume that the $5^{\prime}$-nucleotidase in the pooled Sephadex fractions ( 36 to 40 ) is at least $90 \%$ pure because $28 \mu \mathrm{g}$ protein were applied and the amido black staining technique used would detect at least $2 \mu \mathrm{g}$ of any other protein present (unpublished results). The pooled Sephadex fractions ( 36 to 40 ) were stored at $4{ }^{\circ} \mathrm{C}$ in buffer A (where they retained at least $90 \%$ of their activity after 4 weeks) and were used as a source of pure 5'-nucleotidase in further experiments.

\section{$S D S-P A G E$ and urea-PAGE}

In the light of previous observations concerning the release of enzymes by osmotic shock treatment, as discussed in the Introduction, it was of interest to examine whether $5^{\prime}$-nucleotidase consisted of sub-units. The purified 5'-nucleotidase was therefore subjected to SDS-PAGE and urea-PAGE, both techniques which are known to dissociate proteins into single polypeptide chains that can be separated on the basis of molecular weight (Weber \& Osborn, 1969; Uyemura \& Lehman, 1976). Molecular weight estimates of $66000 \pm 2000$ and $72000 \pm 2000$ were obtained for the two bands of protein observed in all but one 5 '-nucleotidase sample. Thus, $E$. coli $5^{\prime}$-nucleotidase has not been demonstrated to consist of sub-units under conditions which are known to dissociate oligomeric proteins (Weber \& Osborn, 1969). The two bands observed could correspond to the two isoenzymic forms revealed by gel exclusion chromatography. Dvorak \& Heppel (1968) observed two bands of protein during an examination of pure $5^{\prime}$-nucleotidase by PAGE under non-dissociative conditions. We observed only a single band under similar conditions.

The molecular weight estimates of the two isoenzymes obtained by PAGE are much higher than those obtained by Neu (1967a) (52000) and Wyatt (1972) (46 770) using gel exclusion chromatography. Using gel exclusion chromatography we estimated values of 48500 for the main $5^{\prime}$-nucleotidase peak, which is in good agreement with the results of Neu (1967a) and 
Wyatt (1972), and 59000 for the isoenzyme of higher molecular weight. The isoenzyme of 66000 molecular weight revealed by SDS-PAGE presumably corresponds to the main $5^{\prime}$-nucleotidase peak of molecular weight 48500 . Thus it is possible that $5^{\prime}$-nucleotidase is an elongated molecule because SDS-PAGE gives true shape-independent molecular weight estimates (Weber \& Osborn, 1969) whereas those obtained by gel exclusion chromatography are shape-dependent (Andrews, 1964). If this is the case then the release of $5^{\prime}$-nucleotidase during osmotic shock can be explained in terms of the molecular sieving hypothesis in that 5 '-nucleotidase is probably sufficiently elongated to allow it to pass through the cell wall which restricts the release of globular $\beta$-lactamases of molecular weight 30000 or more (Smith \& Wyatt, 1974).

\section{Membrane filtration}

To investigate further the hypothesis that $5^{\prime}$-nucleotidase is an elongated molecule, its molecular weight was estimated by membrane filtration. Membrane filters are available that exclude proteins above a certain molecular weight. This exclusion is, however, dependent not only on molecular weight but also on the shape of the protein. Hence, with these filters it was hoped to set up a system analogous to that during osmotic shock in that molecules were being forced across a molecular sieve.

Using proteins of known molecular weight, it was found that the molecular weight 'cut-off' points of the membranes were in good agreement with the manufacturer's estimates. Almost equal amounts of enzyme passed through the XM50 and PM30 membranes ( $42 \%$ and $37 \%$, respectively), although none was found in the PM10 filtrate. Thus 5 '-nucleotidase can pass through a membrane which excludes globular proteins of molecular weight greater than 30000 , even though its molecular weight is much larger than 30000 . This situation is analogous to that observed during osmotic shock and is taken as strong evidence that 5 '-nucleotidase is an elongated molecule giving different apparent molecular weight values depending on the method of measurement.

Similar results were obtained with the R46- and R55-specified $\beta$-lactamases, both enzymes passing through the XM50 and PM30 filters, but not the PM10 filter. Both these enzymes are dimeric consisting of sub-units of molecular weight 28400 and 29000 , respectively (Dale \& Smith, 1976), although their molecular weights estimated by gel exclusion chromatography are 44600 and 41200 (Dale, 1971; Dale \& Smith, 1974).

Thus, it seems that the release during osmotic shock of $E$. coli 5 '-nucleotidase and of $\beta$-lactamases is on the basis of molecular size as determined by molecular weight, shape and sub-unit structure. If this is the case, then the scientific fashion of assigning enzymes released by osmotic shock to a specific cellular location, i.e. the periplasm, and those not released to a different location, i.e. cell-bound (Heppel, 1971), would appear to be incorrect. Instead we suggest that little or no conclusions as to cellular location should be drawn from osmotic shock data.

D.F.B. is grateful to the Science Research Council for financial assistance.

\section{REFERENCES}

ANDERson, E. S. \& DATTA, N. (1965). Resistance to penicillins and its transfer in Enterobacteriaceae. Lancet 1, 407-409.

ANDREws, P. (1964). Estimation of the molecular weights of proteins by Sephadex gel-filtration. Biochemical Journal 91, 222-233.

BroAd, D. F. \& SMITH, J. T. (1979). Release of enzymes from bacteria. Journal of Pharmacy and Pharmacology 31, 30P
Chen, P. S., Toribara, T. Y. \& W ARNer, H. (1956). Microdetermination of phosphorus. Analytical Chemistry 28, 1757-1761.

Clowes, R. C. \& Rowley, D. (1954). Some observations on linkage effects in genetic recombination in Escherichia coli K12. Journal of General Microbiology 11, 250-260.

DALE, J. W. (1970). The purification and properties of penicillinases from penicillin-resistant Gram- 
negative bacteria, some of which harbour $R$ factors. Ph.D. thesis, University of London.

DALE, J. W. (1971). Characterization of the $\beta$ lactamase specified by the resistance factor R 1818 in Escherichia coli $\mathrm{K} 12$ and other Gram-negative bacteria. Biochemical Journal 123, 501-505.

Dale, J. W. \& Smith, J. T. (1971). The purification and properties of the $\beta$-lactamase specified by the resistance factor R1818 in Escherichia coli and Proteus mirabilis. Biochemical Journal 123, 493500.

DALE, J. W. \& Smith, J. T. (1974). R.factor mediated $\beta$-lactamases that hydrolyze oxacillin: evidence for two distinct groups. Journal of Bacteriology 119, 351-356.

Dale, J. W. \& Smith, J. T. (1976). The dimeric nature of an R.factor mediated $\beta$-lactamase. Biochemical and Biophysical Research Communications 68, 1000-1005.

Davis, B. D. \& Mingioli, E. S. (1950). Mutants of Escherichia coli requiring methionine or vitamin B12. Journal of Bacteriology 60, 17-28.

Davis, B. J. (1964). Disc electrophoresis. II. Method and application to human serum proteins. Annals of the New York Academy of Sciences 121, 404-427.

DVORAK, H. F. \& HePpel, L. A. (1968). Metalloenzymes released from Escherichia coli by osmotic shock. II. Evidence that 5 '-nucleotidase and cyclic phosphodiesterase are zinc metalloenzymes. Journal of Biological Chemistry 243, 2647-2653.

Hedges, R. W., Datta, N., Kontamichalou, P. \& SMITH, J. T. (1974). Molecular specificities of R.factor-determined $\beta$-lactamases: correlation with plasmid compatibility. Journal of Bacteriology 117, 56-62.

HePPEL, L. A. (1971). The concept of periplasmic enzymes. In Structure and Function of Biological Membranes, pp. 223-247. Edited by L. I. Rothfield. New York: Academic Press.

Mrtchell, P. (1961). Approaches to the analysis of specific membrane transport. In Biology Structure and Function, vol. 2, Proceedings of the First IUB/IUBS International Symposium, pp. 581-
603. Edited by T. W. Goodwin \& O. Lindberg. London \& New York: Academic Press.

Neu, H. C. $(1967 a)$. The 5 -nucleotidase of Escherichia coli. I. Purification and properties. Journal of Biological Chemistry 242, 3896-3904.

Nev, H. C. $(1967 b)$. The 5 -nucleotidase of Escherichia coli. II. Surface localization and purification of 5'-nucleotidase inhibitor. Journal of Biological Chemistry 242, 3905-3911.

NeU, H. C. \& Chou, J. (1967). Release of surface enzymes in Enterobacteriaceae by osmotic shock. Journal of Bacteriology 94, 1934-1945.

Neu, H. C. \& HePpel, L. A. (1964). On the surface localization of enzymes in E. coli. Biochemical and Biophysical Research Communications 17, 215219.

SMITH, J. T. \& WyatT, J. M. (1974). Relation of R.factor and chromosomal $\beta$-lactamase with the periplasmic space. Journal of Bacteriology 117 , 931-939.

Spahr, P. F. \& Hollingworth, B. R. (1961). Purification and mechanism of action of ribonuclease from Escherichia coli ribosomes. Journal of Biological Chemistry 236, 823-831.

UYEMURA, D. \& LeHMAN, I. R. (1976). Biochemical characterization of mutant forms of DNA polymerase I from Escherichia coli. I. The polA12 mutation. Journal of Biological Chemistry 251, 4078-4084.

WADDELL, W. J. (1956). A simple ultraviolet spectrophotometric method for the determination of protein. Journal of Laboratory and Clinical Medicine 48, 311-314.

WEBER, K. \& OsBorN, M. (1969). The reliability of molecular weight determinations by dodecyl sulphate-polyacrylamide gel electrophoresis. Journal of Biological Chemistry 224, 44064412.

Witchitz, J. L. \& Chabbert, Y. A. (1971). High level transferable resistance to gentamicin. Journal of Antibiotics 24, 137-139.

WYATT, J. M. (1972). Episomal and chromosomal bacterial enzymes: their retention and release. $\mathrm{Ph} . \mathrm{D}$. thesis, University of London. 
